\title{
Dermal Uptake of Benzophenone-3 from Clothing
}

Morrison, Glenn C.; Bekö, Gabriel; Weschler, Charles J.; Schripp, Tobias; Salthammer, Tunga; Hill, Jonathan; Andersson, Anna-Maria; Toftum, Jørn; Clausen, Geo; Frederiksen, Hanne

\section{Published in:}

Environmental Science and Technology

Link to article, DOI:

10.1021/acs.est.7b02623

Publication date:

2017

Document Version

Peer reviewed version

Link back to DTU Orbit

Citation (APA):

Morrison, G. C., Bekö, G., Weschler, C. J., Schripp, T., Salthammer, T., Hill, J., Andersson, A-M., Toftum, J., Clausen, G., \& Frederiksen, H. (2017). Dermal Uptake of Benzophenone-3 from Clothing. Environmental Science and Technology, 51(19), 11371-11379. https://doi.org/10.1021/acs.est.7b02623

\section{General rights}

Copyright and moral rights for the publications made accessible in the public portal are retained by the authors and/or other copyright owners and it is a condition of accessing publications that users recognise and abide by the legal requirements associated with these rights.

- Users may download and print one copy of any publication from the public portal for the purpose of private study or research.

- You may not further distribute the material or use it for any profit-making activity or commercial gain

- You may freely distribute the URL identifying the publication in the public portal 


\section{Dermal uptake of benzophenone-3 from clothing}

2 Glenn C. Morrison ${ }^{1, *}$, Gabriel Bekö ${ }^{2}$, Charles J. Weschler ${ }^{2,3}$, Tobias Schripp ${ }^{4,5}$, Tunga

3 Salthammer $^{4}$, Jonathan Hill ${ }^{1}$, Anna-Maria Andersson ${ }^{6,7}$, Jørn Toftum ${ }^{2}$, Geo Clausen ${ }^{2}$, Hanne

4 Frederiksen $^{6,7}$

$5{ }^{1}$ Missouri University of Science and Technology, Civil, Architectural and Environmental

6 Engineering, Rolla, MO, 65409, USA

$7 \quad{ }^{2}$ Technical University of Denmark, International Centre for Indoor Environment and Energy,

8 Department of Civil Engineering, Lyngby, Denmark

$9{ }^{3}$ Rutgers University, Environmental and Occupational Health Sciences Institute, Piscataway,

10 New Jersey, USA

$11{ }^{4}$ Fraunhofer WKI, Department of Material Analysis and Indoor Chemistry, Braunschweig,

12 Germany

$13{ }^{5}$ German Aerospace Center, Institute of Combustion Technology, Stuttgart, Germany

$14{ }^{6}$ Department of Growth and Reproduction, Rigshospitalet, University of Copenhagen,

15 Copenhagen, Denmark

$16{ }^{7}$ International Center for Research and Research Training in Endocrine Disruption of Male

17 Reproduction and Child Health (EDMaRC), Rigshospitalet, University of Copenhagen, Denmark

18 *Corresponding author

19 Glenn C. Morrison

20 Missouri University of Science and Technology

$21221 \mathrm{BCH}, 1401 \mathrm{~N}$. Pine St.

22 Rolla, $M O 65409$

23 Phone: 573 341-7192

24 Email:gcm@mst.edu 
Key words

27 benzophenone-3, clothing, dermal uptake, exposure, biomonitoring

\section{Abstract}

29 Benzophenone-3 (aka BP-3, oxybenzone) is added to sunscreens, plastics and some coatings to

30 filter UV radiation. The suspected endocrine disruptor BP-3 has been detected in the air and

31 settled dust of homes and is expected to redistribute from its original sources to other indoor

32 compartments, including clothing. Given its physical-chemical properties, we hypothesized that

33 dermal uptake from clothing could contribute to the body burden of this compound. First, cotton

34 shirts were exposed to air at an elevated concentration of BP-3 for 32 days; the final air

35 concentration was $4.4 \mu \mathrm{g} / \mathrm{m}^{3}$. Then three participants wore the exposed shirts for 3 hours. After

36 this 3 -h exposure, participants wore their usual clothing while collecting urine samples for the

37 next 48 hours. Urine was analyzed for BP-3 and a metabolite, BP-1, and six other UV filters. The

38 rate of urinary excretion of the sum of BP-1 and BP-3 increased for all participants during and

39 following the 3-hour exposure. The summed mass of BP-1 and BP-3 excreted during the first 24

40 hours attributable to wearing exposed t-shirts were 12, 9.9 and $82 \mu \mathrm{g}$ for participants 1,2 and 3

41 respectively. Analysis of these results coupled with predictions of steady-state models suggest

42 that dermal uptake of BP-3 from clothing could meaningfully contribute to overall body burden.

\section{Introduction}

44 2-Hydroxy-4-methoxybenzophenone commonly known as benzophenone-3 (BP-3), is an

45 ultraviolet (UV) light filter used in sunscreen, cosmetics and other personal care products. It is

46 also added to plastics and coatings to reduce UV damage in industrial and consumer products ${ }^{1}$.

$47 \quad$ BP-3 and its metabolites have been found in blood and urine of people in the US, Europe and

48 China $^{2-5}$. Based on its weak estrogenic activity as shown in several in vitro and in vivo studies, 
49 BP-3 has been flagged as a suspected endocrine disruptor and is on the EU-commission priority

50 list of potential endocrine disrupting chemicals ${ }^{6}$. The endocrine disrupting ability of BP-3 was

51 recently confirmed in a study showing a skewed sex ratio favoring females in zebrafish following

52 developmental exposure ${ }^{7}$. In addition, recent in vitro studies have shown that BP-3 and some

53 other chemical UV filters mimic the effect of progesterone on the CatSper $\mathrm{Ca}^{2+}$ channel in

54 human sperm cell, triggering multiple sperm cell functions essential for fertilization of the egg

55 and exposure to BP-3 is therefore suspected to impact on male fertility ${ }^{8}$. Furthermore, the major

56 metabolite of BP-3, 2,4-dihydroxybenzophenone or benzophenone-1 (BP-1), is a suspected

57 endocrine disruptor and is included on the Substitute it Now (SIN) list ${ }^{6}$. In vitro studies have

58 identified both estrogenic and anti-androgenic activity for BP-1 ${ }^{9}$, and urinary BP-1 has been

59 shown to be associated with endometriosis in US women ${ }^{10}$.

60 Dermal uptake from personal care products and cosmetic products is believed to constitute the

61 major exposure pathway for BP-3. A number of studies have documented dermal uptake of BP-3

62 following its topical application ${ }^{11-16}$ In a human subject trial, Janjua et al. ${ }^{16}$ observed a rapid rise

63 in the BP-3 concentration in plasma and urine after applying a BP-3 containing cream to $2 \mathrm{~m}^{2}$ of

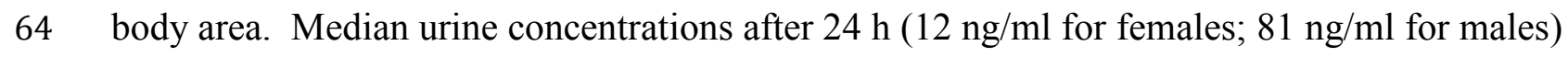

65 were within the $25-75$ th percentile range observed in the US population $(5.8-94 \mathrm{ng} / \mathrm{ml})^{17}$, but

66 somewhat higher than the 25-75th percentile range observed in Danish pregnant women (1.1-14

$67 \mathrm{ng} / \mathrm{ml})$ and young Danish men from the general population $(1.3-7.8 \mathrm{ng} / \mathrm{ml})^{18}$. Zamoiski et al. ${ }^{19}$

68 observed a positive correlation between self-reported sunscreen use and urinary BP-3. In an

69 intervention study, Harley et al. ${ }^{20}$ observed an average 36\% decrease in urinary BP-3

70 concentrations in adolescent girls after being encouraged to use BP-3-free personal care products 
71 provided by the researchers. BP-3 was found in most personal care products tested by Liao et

72 al. $^{21}$ and they estimated that $80 \%$ of dermal exposure is due to skin lotions and face creams.

73 Dermal uptake of BP-3 may also occur from contaminated air and clothing, although uptake

74 from either has not been directly observed. Weschler and Nazaroff ${ }^{22}$ predicted that dermal uptake

75 to bare skin from indoor air could contribute substantially to the body-burden of many semi-

76 volatile organic compounds (SVOCs). Weschler et al. ${ }^{23}$ supported these predictions by

77 demonstrating the dermal uptake of two phthalates from air for six bare-skinned subjects.

78 Applying the Weschler and Nazaroff model, Morrison et al. ${ }^{24}$ predicted that dermal uptake of

79 BP-3 from the gas phase is probable, if it is present in indoor air. Wan et al. ${ }^{25}$ observed BP-3

80 concentrations in the air of US homes ranging from 0.19 to $72 \mathrm{ng} / \mathrm{m}^{3}$. Although they estimated

81 that inhalation would not be an important pathway, they did not consider the potential for dermal

82 uptake from air or clothing.

83 Dermal uptake from air can also be influenced or even enhanced by wearing clothing that had

84 been exposed to, or impregnated with, skin-permeable chemicals ${ }^{26-32}$. Xue et al ${ }^{33}$ detected BP-3

85 in $70 \%$ of newly purchased infant clothing and estimated a mean dermal dose of about $7 \mathrm{ng} / \mathrm{kg}$

86 body weight /day. Clothing can also have a high sorptive capacity for SVOCs present in homes

87 and other buildings ${ }^{34-39}$, resulting in high-intensity sources of exposure close to the skin.

88 Therefore, BP-3 adsorbed to clothing from indoor air may meaningfully contribute to overall

89 body-burden of BP-3. While cosmetics and other personal care products can contribute

90 significantly to exposure ${ }^{19,20}$, we are concerned about the persistent, all-year background

91 exposure which is seemingly independent of sunscreen or personal care product application ${ }^{40}$.

92 Efforts to reduce BP-3 in these products ${ }^{41}$ may have a limited effect if substantial amounts are

93 also absorbed from indoor air and clothing. 
94 The objective of this research is to investigate the hypothesis that dermal uptake can occur for

95 individuals wearing clothing that has had the opportunity to sorb BP-3 from air.

\section{Methods.}

97 Shirt dosing and participant exposure experiments took place at the Technical University of

98 Denmark (DTU), Lyngby, Denmark. Plasma and blood analysis took place at the Department of

99 Growth and Reproduction, Rigshospitalet, Copenhagen, Denmark. BP-3 air samples were

100 collected at DTU and analyzed at Fraunhofer, WKI Braunschweig, Germany. The research

101 protocol was approved by the Capital Region of Denmark Committee for Research Ethics (case

102 no. H-16018670).

103 Shirts. Five new, dark blue, long-sleeve t-shirts were purchased on May 4, 2016 from a local

104 department store in Lyngby, Denmark. They were made of $100 \%$ cotton according to the

105 attached tag. They were identical except for size (one small, one medium, two large). The

106 measured density and thickness were $0.28 \mathrm{~g} / \mathrm{cm}^{3}$ and $0.062 \mathrm{~cm}$, respectively. They were washed

107 in a mechanical washer with hot water and a fragrance-free detergent. They were dried with an

108 electric hot air dryer. Four of the t-shirts were then transferred to the dosing chamber, while the

109 fifth was kept as an unexposed control.

110 BP-3. BP-3 of 98+ \% purity was purchased from Alfa Aesar, Thermo Fisher GmbH, Karslruhe,

111 Germany. The properties of BP-3 can be found in Supporting Information, Table S1.

112 Shirt dosing chamber and shirt preparation. A small closet-sized, sealed dosing chamber was

113 constructed to expose shirts to an elevated air concentration of BP-3. The chamber was

114 constructed of foam-board covered in aluminum foil with a metal internal support frame.

115 Approximately $20 \mathrm{~g}$ of BP-3, a solid at room temperature, was heated until melted and brushed 
116 onto three clean $0.15 \mathrm{~m}^{2}$ aluminum sheet pans to increase the exposed surface area. These pans

117 were placed on the floor of the chamber and a small muffin fan was installed to enhance air

118 movement. Four shirts were hung inside-out on plastic hangers in the sealed chamber for 32

119 days. On day 27, the pans coated with BP-3 were removed from the chamber, but the shirts were

120 not removed, and the chamber was re-sealed. Removing the pans for several days allows shirts to

121 equilibrate with the surrounding air without an emission source driving sorption. Chamber

122 concentrations were measured (see Air concentrations section) on day 31 and shirts were worn

123 by participants immediately after being removed from the dosing chamber on day 32 .

124 Participant exposure chamber. The participant exposure chamber has been described in detail

125 elsewhere ${ }^{23}$. Briefly, the $55 \mathrm{~m}^{3}$ chamber is a converted room with a controllable ventilation

126 system operated at an air exchange rate of $0.7 / \mathrm{h}$. Unlike prior dermal uptake experiments ${ }^{23,28}$, the

127 concentration of the target analyte was not intentionally elevated in the chamber and participants

128 did not wear breathing hoods during the three-hour exposure period. Even though the

129 participants were wearing shirts with sorbed BP-3, we anticipated that the breathing zone

130 concentration would be low because the chamber was well ventilated and well mixed with fans.

131 As a check of this assumption, the air concentration near the breathing zone was measured to

132 determine if inhalation contributed significantly to total dose (see Air concentrations section).

133 The temperature was between $20-23^{\circ} \mathrm{C}$ during the exposure period.

134 Participants. Prior to the exposure, the 3 male participants, all with normal characteristics

135 (Table 1) were asked not to apply any sunscreen or any other personal care products that may

136 have contained UV filters two days before and two days after the three-hour exposure period.

137 The participants were also asked not to shower after exposure until the following morning. Each

138 participant chose a shirt that they felt fit them best. The shirts were normal-to-close fitting, but 
139 neither skin-tight nor very loose. See Supporting Information Figure S1 for images of

140 participants wearing shirts.

141 Table 1. Personal characteristics.

\begin{tabular}{|c|c|c|c|}
\hline & Participant 1 & Participant 2 & Participant 3 \\
\hline Age (y) & 27 & 36 & 51 \\
\hline Weight (kg) & 73 & 71 & 84 \\
\hline Height (m) & 1.80 & 1.80 & 1.84 \\
\hline BMI $\left(\mathrm{kg} / \mathrm{m}^{2}\right)$ & 22.5 & 21.9 & 24.8 \\
\hline BSA $\left(m^{2}\right)$ & 1.92 & 1.89 & 2.08 \\
\hline
\end{tabular}

BMI; body mass index is calculated as (body weight $(\mathrm{kg})) /(\text { height }(\mathrm{m}))^{2}$

143 BSA; body surface area (based on method of DuBois and DuBois ${ }^{42}$

144 Urine sample collection. The participants collected the total volume of three consecutive first-

145 morning urine voids, the first one on the morning prior to exposure (day 1). During the period

146 between the first-morning urination on the exposure day and the first-morning urination the

147 following day (day 2), they also collected the total volume of each spot urine voids separately.

148 Finally, during the period between the first- morning urination on day 2 and the first-morning

149 urination on day 3 they collected all spot urine voids as one pool (Figure 1). All urine samples

150 were collected in $1 \mathrm{~L}$ or $2.5 \mathrm{~L}$ polyethylene bottles. 


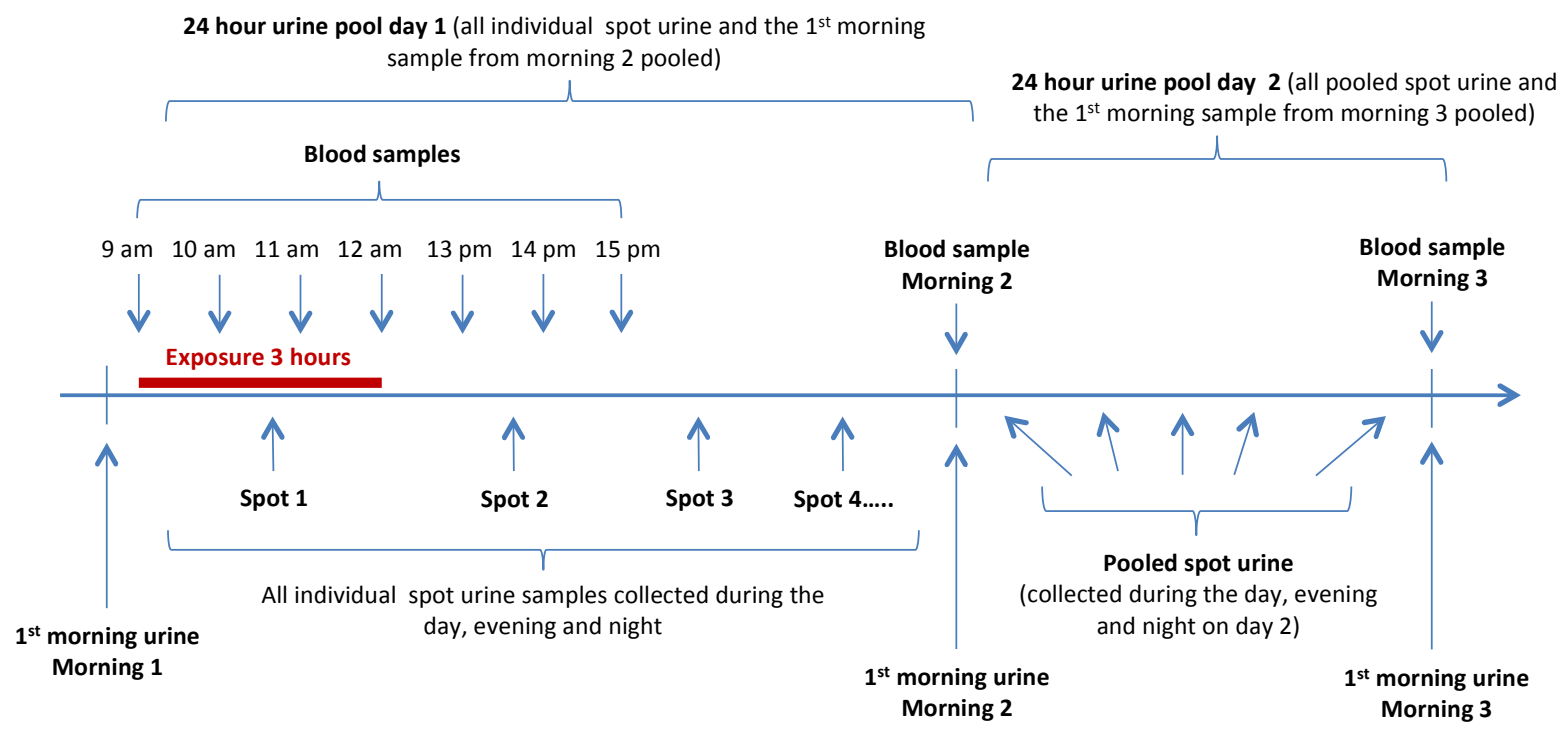

152 Figure 1. Schedule of urine and blood sample collection

153 In the chemical laboratory, urine samples were handled immediately after being received. All

154 urine samples were weighed and $5 \mathrm{ml}$ aliquots of all samples were stored. Subsequently a 24-

155 hour urine pool for day 1 was prepared by pooling the remaining volume of all spot urine

156 samples of day 1 together with the first-morning urine of day 2. For a 24 hour urine pool of day 2

157 the remaining volume of the spot urine pool from day 2 was combined with the first-morning

158 urine of day 3 . Aliquots of all urine samples were stored at $-20^{\circ} \mathrm{C}$ until chemical analysis.

159 Shortly before exposure began, a peripheral venous catheter (venflon) was placed in the

160 antecubital vein of each participant. Through this catheter a blood sample was collected

161 immediately before the start of the exposure period and five additional blood samples were

162 collected one hour apart over the next five hours after which the catheter was removed.

163 Additionally, blood samples were taken in the morning of day 2 and 3 by venipuncture of the

164 cubital vein (Figure 1). Blood samples were allowed to clot and serum was obtained by 
165 centrifugation for $10 \mathrm{~min}$ at $2000 \mathrm{~g}$ and subsequently aliquoted and stored at $-20^{\circ} \mathrm{C}$ until chemical 166 analysis.

167 Chemical analyses. All urine and serum samples were analyzed for the free and total (sum of 168 free and conjugated) content of eight different UV filters (Supporting Information, Table S2) by 169 a recently developed method for UV filters analyzed in urine using isotope dilution TurboFlow170 liquid chromatography - tandem mass spectrometry (LC-MS/MS) with prior enzymatic

171 deconjugation. ${ }^{43}$ In addition, the method was optimized and validated for analysis of UV filters

172 in serum. The limit of detections (LOD) for BP-1 and BP-3 were respectively 0.25 and 0.28

$173 \mathrm{ng} / \mathrm{ml}$ in urine and 0.13 and $0.12 \mathrm{ng} / \mathrm{ml}$ in serum. Other LODs are shown in Supporting 174 Information, Table S2.

175 In short, the samples were analyzed in four batches for, respectively, urine and serum samples

176 with and without enzymatic deconjugation. Each batch included standards for calibration curves,

17724 urine or 27 serum samples, three blanks, and control material of respectively urine or serum

178 containing three samples pooled unspiked, three samples pooled spiked with native UV filter

179 standards at a low level and three samples pooled spiked at a high level.

180 The recovery for all analytes spiked in urine or serum in both spike levels was $\geq 90 \%$, except for

181 5-chloro-2-hydroxybenzophenone (BP-7) at low (70\%) and high (75\%) spike levels in serum and 182 at both spike levels (>79\%) in urine.

183 Air concentrations. Air samples were collected by drawing 10-20 L of air through sorbent tubes 184 containing Tenax-TA (Buchem, BV) with a calibrated sampling pump set at 0.1-0.2 L/min.

185 Three samples were taken from the shirt dosing chamber one day before the participant exposure 186 experiments, and a field blank was set aside for later analysis. The field blank was treated exactly 
187 as other tubes except that no air sample was collected. Air samples were also collected from the

188 breathing zone of two participants during the $3 \mathrm{~h}$ exposure period. The sample tube was attached

189 to the participant's work desk, with the inlet approximately $20-30 \mathrm{~cm}$ from the nose and mouth

190 region. The tubes were analyzed for BP-3 via thermal desorption (TD-100, Markes Int.) and gas

191 chromatography (7890B GC, Agilent Technologies) coupled with mass spectrometry (5977A MSD,

192 Agilent Technologies). Separation was performed on a DB-5MS column (60 m x $0.25 \mathrm{~mm}$ x 0.25

$193 \mu \mathrm{m})$. The mass spectrometer was operated in selected ion monitoring mode using $\mathrm{m} / \mathrm{z} 227$ as

194 quantifier and m/z 151 as qualifier mass. Calibration information and determination of LOD is

195 shown in Supplementary Information (Section S1 and Figures S2 and S3). We did not quantify

196 airborne BP-1 in the shirt dosing chamber or in breathing zone.

197 Extraction from fabrics. After exposure, each shirt was placed into separate, cleaned glass jars 198 and shipped to Missouri S\&T for analysis. Four square pieces, approximately $10 \mathrm{~cm}^{2}$ each, were 199 cut from four quadrants of the back of each shirt. Each piece was extracted in $5 \mathrm{ml}$ of

200 acetonitrile, sonicated for $30 \mathrm{~min}$ and filtered. The extract was analyzed by injecting $15 \mu 1$ into a 201 Phenomenex Syrengi 4u Hydro-RP 80A column on a LabTech UV-600 HPLC using 10\% water 202 and $90 \%$ acetonitrile in gradient mode with detection at $325 \mathrm{~nm}$. A seven point calibration was 203 performed between $0.5 \mu \mathrm{g} / \mathrm{ml}$ and $25 \mu \mathrm{g} / \mathrm{ml}$. The limit of detection was estimated to be 0.06 $204 \mu \mathrm{g} / \mathrm{ml}$, which corresponded to approximately $1.7 \mu \mathrm{g} / \mathrm{g}$ of shirt material.

205 Calculation of excretion mass and rates. Excreted mass was calculated by multiplying the 206 urine concentration by the urine mass and density (assumed to be $1 \mathrm{~g} / \mathrm{cm}^{3}$ ). The excretion mass 207 rate for each interval was calculated by dividing the excreted mass for each urination by the 208 elapsed time since the previous urination. The time of urination on the evening prior to the first 209 morning urination was not recorded. We assume that this time is identical to the time interval 
210 between second morning urination and the last urination of the previous evening. To estimate the

211 mass excreted that is attributable to wearing the exposed t-shirt, the excretion mass rate was

212 integrated over the first 24 hours (up to and including the $2^{\text {nd }}$ morning urination) after subtracting

213 out the background rate associated with the first morning urination. For results in which BP-1

214 and BP-3 are combined, such as summed concentration, excreted mass and excretion rate, the

215 BP-1 result is converted to BP-3 equivalents by multiplying it by the ratio of the molecular

216 weights: (228.2 g BP-3/mol)/(214.2 g BP-1/mol).

\section{Results and discussion}

219 Based on three replicate samples, the BP-3 air concentration in the shirt dosing chamber on day

22031 was $4.4 \pm 0.5 \mu \mathrm{g} / \mathrm{m}^{3}$. At $25^{\circ} \mathrm{C}$, based on vapor pressure estimates from SPARC, the saturation

221 air concentration over pure BP-3 is $9.3 \mu \mathrm{g} / \mathrm{m}^{3}$; based on estimates from EPI Suite, $81 \mu \mathrm{g} / \mathrm{m}^{3}$

222 (Table S1). In either case, the shirt dosing chamber concentration was a significant fraction of

223 the saturation concentration under these conditions. During the human subject exposure

224 experiments, the air concentration in the breathing zone was below the limit of detection $(0.3$

$\left.225 \mu \mathrm{g} / \mathrm{m}^{3}\right)$

\section{Clothing extraction}

227 The BP-3 concentrations in clothing are shown in Table 2 for an unworn shirt and for shirts after

228 they were worn by subjects. In all dosed shirt samples the concentrations were well above the

229 limit of detection, ranging from 61 to $132 \mu \mathrm{g} / \mathrm{g}$. Participant 1 wore the shirt with the highest

230 average concentration and lowest relative standard deviation (RSD). The shirt concentrations

231 were about $40 \%$ lower for participants 2 and 3 but the RSD was much higher indicating that the 
232 sorption from the dosing chamber air was not as complete or as uniform for their shirts. The

233 dosed but unworn shirt absorbed less than half of BP-3 compared with the shirt worn by

234 participant 1 . Non-uniformities in mixing within the chamber or spacing between the shirts may

235 have accounted for the observed variation among and within shirt samples. Xue et al. ${ }^{33}$ observed

236 a mean BP-3 concentration in fabrics of $12.6 \mathrm{ng} / \mathrm{g}$, which is about $10^{4}$ times lower than measured

237 here. The shirts in the current study were exposed to BP-3 at a concentration far greater than

238 those reported by Wan et al. ${ }^{25}$ for air in buildings. To provide an approximate (order-of-

239 magnitude) estimate of the anticipated concentrations in the shirts exposed to BP-3 in a residence

240 we first assume linear sorption, then we multiply the observed range in the current study (61 to

$241132 \mu \mathrm{g} / \mathrm{g})$ by the ratio of the mean value reported by Wan et al. $\left(1.18 \mathrm{ng} / \mathrm{m}^{3} \text { for public places }\right)^{25}$

242 and the air concentration in the exposure chamber $\left(4400 \mathrm{ng} / \mathrm{m}^{3}\right)$. The resulting range, 16-35

$243 \mathrm{ng} / \mathrm{m}^{3}$, is centered in the range reported by Xue et al. $\left(<2.2-41.8 \mathrm{ng} / \mathrm{m}^{3}\right)^{33}$. This suggests that

244 the BP-3 identified by Xue et al. may have derived from building air instead of from the

245 manufacturing process. This is supported by the observation of Xue et al. that there was no

246 significant difference between raw fabrics and purchased clothing, or among fabric materials

247 (e.g. cotton vs. polyester) in their study ${ }^{33}$. In other words, the BP-3 concentration in clothing may

248 be more dependent on its most recent environmental conditions, such as room air, than its

249 composition or manufacturing process.

250 Table 2. Concentration of BP-3 in t-shirts, averages of 4 samples of each shirt. Limits of

251 detection (LOD) were $1.7 \mu \mathrm{g} / \mathrm{g}, 0.03 \mu \mathrm{g} / \mathrm{cm}^{2}$, and $0.48 \mu \mathrm{g} / \mathrm{cm}^{3}$.

\begin{tabular}{|l|c|c|c|c|}
\hline & $\begin{array}{l}\text { mass BP-3/ } \\
\text { mass cloth } \\
(\mu \mathrm{g} / \mathrm{g})\end{array}$ & $\begin{array}{l}\text { mass BP-3/ } \\
\text { area shirt } \\
(\mu \mathrm{g} / \mathrm{cm} 2)\end{array}$ & $\begin{array}{l}\text { mass BP-3/ } \\
\text { volume shirt } \\
(\mu \mathrm{g} / \mathrm{cm} 3)\end{array}$ & RSD* \\
\hline Participant 1 & 132 & 2.3 & 37 & 0.04 \\
\hline Participant 2 & 81 & 1.4 & 23 & 0.26 \\
\hline Participant 3 & 80 & 1.4 & 22 & 0.30 \\
\hline
\end{tabular}




\begin{tabular}{|l|c|c|c|c|}
\hline $\begin{array}{l}\text { Exposed but } \\
\text { not worn }\end{array}$ & 61 & 1.1 & 17 & 0.13 \\
\hline $\begin{array}{l}\text { Unexposed } \\
\text { (blank) }\end{array}$ & $<$ LOD & $<$ LOD & $<$ LOD & \\
\hline
\end{tabular}

$252 * \mathrm{RSD}=$ relative standard deviation for 4 samples of same shirt

253 Urine

254 Of the eight target analytes, only BP-1 and BP-3 were detected consistently in both first-morning 255 and spot urine. Major results for these two analytes are shown in Table 3. The concentration of 3-

256 benzylidene camphor (3-BC) was above detection limit in all samples from subject 1, suggesting a

257 unique source for that subject. All other analytes were below detection limits in most urine

258 samples (Supplementary Information, Table S3). 
Table 3. Urinary concentrations, mass and excretion rates

\begin{tabular}{|c|c|c|c|c|c|c|}
\hline & \multicolumn{2}{|c|}{ Participant 1} & \multicolumn{2}{|c|}{ Participant 2} & \multicolumn{2}{|c|}{ Participant 3} \\
\hline & BP-1 & BP-3 & BP-1 & BP-3 & BP-1 & BP-3 \\
\hline \multicolumn{7}{|c|}{ First morning urination $(\mathrm{ng} / \mathrm{ml})$} \\
\hline Morning 1 & 7.07 & 29.6 & 2.23 & 7.38 & 3.39 & 16.7 \\
\hline Morning 2 & 7.39 & 22.4 & 1.65 & 3.53 & 14.5 & 79.5 \\
\hline Morning 3 & 4.58 & 16.5 & 0.71 & 2.14 & 3.81 & 31.7 \\
\hline \multicolumn{7}{|c|}{$24 \mathrm{~h}$ urine (ng/kg bw/24h) } \\
\hline Pool 1 & 108 & 346 & 64.6 & 202 & 178 & 1153 \\
\hline Pool 2 & 68.1 & 168 & 24.8 & 54.7 & 94.9 & 678 \\
\hline \multicolumn{7}{|c|}{ First morning excretion rate $(\mu \mathrm{g} / \mathrm{h})$} \\
\hline & 0.18 & 0.74 & 0.09 & 0.29 & 0.22 & 1.1 \\
\hline \multicolumn{7}{|c|}{ Total excreted after exposure up to and including second morning urination $(\mu \mathrm{g})$} \\
\hline Individual & 7.9 & 25 & 4.6 & 14 & 15 & 97 \\
\hline Sum of BP-1 and BP-3 (BP-3 equiv.) & \multicolumn{2}{|c|}{34} & \multicolumn{2}{|c|}{19} & \multicolumn{2}{|c|}{110} \\
\hline \multicolumn{7}{|c|}{ Mass excreted ${ }^{*}(\mu \mathrm{g})$} \\
\hline Sum of BP-1 and BP-3 (BP-3 equiv.) & \multicolumn{2}{|c|}{12} & \multicolumn{2}{|c|}{9.9} & \multicolumn{2}{|c|}{82} \\
\hline \multicolumn{7}{|c|}{ Normalized mass excreted ${ }^{* *}\left(\mu \mathrm{g} /\left(\mathrm{m}^{2}\right) /\left(\mu \mathrm{g} / \mathrm{m}^{3}\right)\right.$} \\
\hline Sum of BP-1 and BP-3 (BP-3 equiv.) & \multicolumn{2}{|c|}{2.7} & \multicolumn{2}{|c|}{2.4} & \multicolumn{2}{|c|}{18} \\
\hline \multicolumn{7}{|c|}{ Average ratio of the concentrations of BP-1 and BP-3 } \\
\hline BP-1/BP-3 & \multicolumn{2}{|c|}{0.31} & \multicolumn{2}{|c|}{0.35} & \multicolumn{2}{|c|}{0.15} \\
\hline
\end{tabular}

$262{ }^{*}$ Mass excreted, corrected for background excretion rate during first $24 \mathrm{~h}$ up to and including second

263 morning urination, $(\mu \mathrm{g})$

$264{ }^{* *}$ Mass excreted during first $24 \mathrm{~h}$, normalized by shirt-covered surface area $\left(0.5^{*} \mathrm{BSA}\right)$ and dosing BP-3

265 air concentration, $\left(\mu \mathrm{g} /\left(\mathrm{m}^{2}\right) /\left(\mu \mathrm{g} / \mathrm{m}^{3}\right)\right.$

266 Concentrations and accumulated urinary excretion of BP-1 and BP-3 are shown in Figure 2. Pre-

267 exposure (background) BP-3 first-morning urine concentration from participants 1, 2 and 3 were

26830,7 and $17 \mathrm{ng} / \mathrm{ml}$, respectively. Their individual peak concentrations in subsequent spot urines

269 were 38,32 and $79 \mathrm{ng} / \mathrm{ml}$, respectively. These values are comparable to values within the 25 - 
$27075^{\text {th }}$ percentile of the US population $(5.8-94 \mathrm{ng} / \mathrm{ml})^{17}$, mostly lower than the mean for an

271 Australian population $(61.5 \mathrm{ng} / \mathrm{ml})^{44}$, but much higher than values reported for Danish young

272 men $\left(25-75^{\text {th }}\right.$ percentile $\left.=1.3-7.8 \mathrm{ng} / \mathrm{ml}\right)$ and other Danish population groups such as

273 kindergarten children, school children and adolescents, pregnant women and children and their

274 mothers ${ }^{18,40,43}$. Chinese young adults $(0.55 \mathrm{ng} / \mathrm{ml} \text { median; } 0.26 \mathrm{ng} / \mathrm{ml} \text { geometric mean })^{4,45}$ or

275 Belgian adults $(1.3 \mathrm{ng} / \mathrm{ml} \text { mean })^{46}$. The median peak urine concentration of BP-3 after whole-

276 body application of a BP-3 containing lotion was 44 and $81 \mathrm{ng} / \mathrm{ml}$ for female and male subjects,

277 respectively ${ }^{16}$.

278 There are fewer published measurements of urinary BP-1 available for comparison with subjects

279 in this study. Background BP-1 urine concentration from participants 1, 2 and 3 in the current

280 study were 7.1, 2.2 and $3.4 \mathrm{ng} / \mathrm{ml}$, respectively. Their peak concentrations were $10.1,8.6$ and

$28114.5 \mathrm{ng} / \mathrm{ml}$ respectively. In Chinese adults, Zhang et al. ${ }^{4}$ reported a geometric mean of 0.28

$282 \mathrm{ng} / \mathrm{ml}$. Frederiksen et al. ${ }^{43}$ observed a median concentration in Danish children and adolescents

283 of $0.54 \mathrm{ng} / \mathrm{ml}$ in $24 \mathrm{~h}$ urine. 

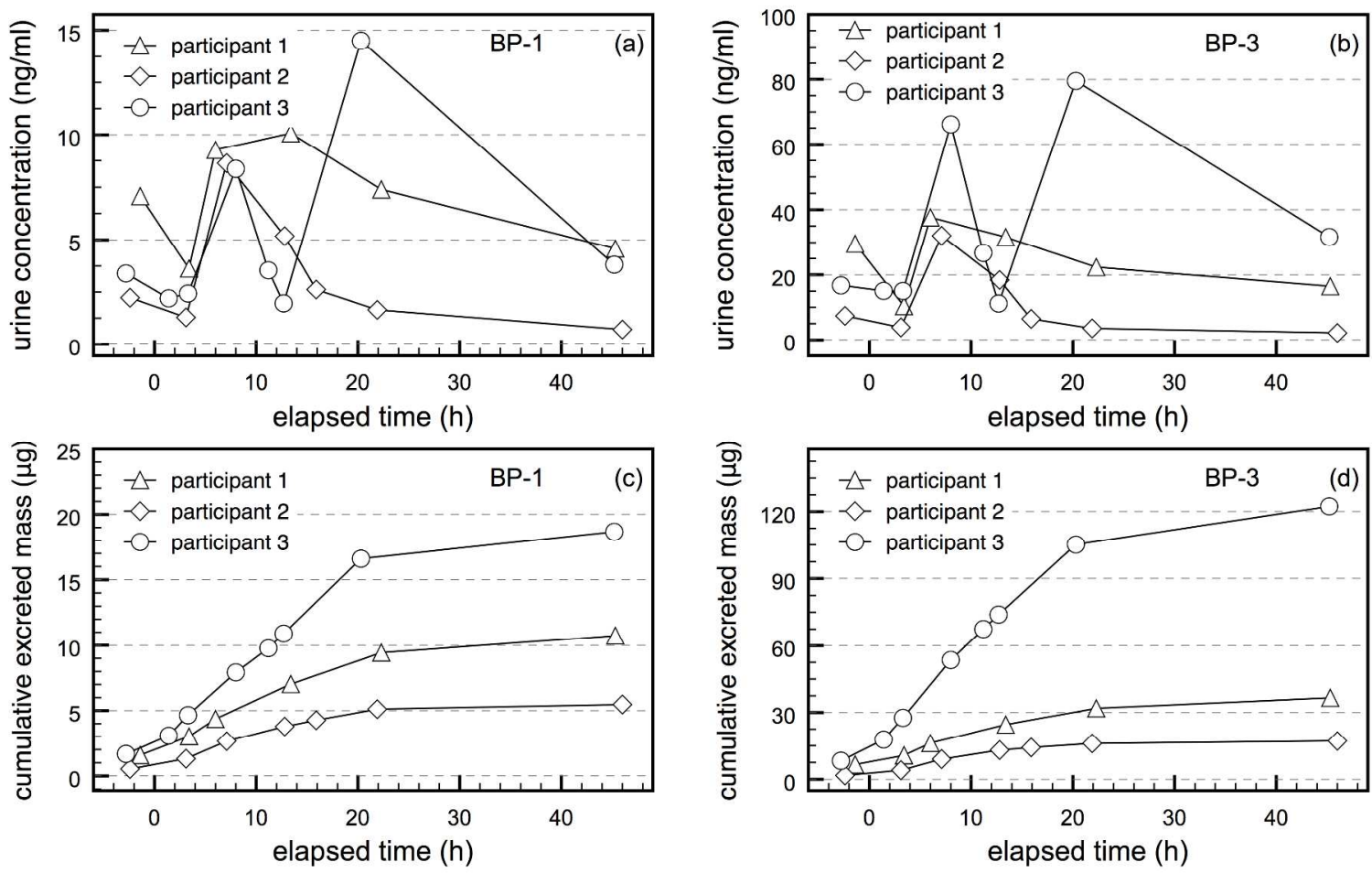

Figure 2. Urine concentration of BP-1 (a) and BP3 (b), and accumulated urinary excretion of BP-1 (c) and BP-3 (d). The x-axis shows the elapsed time from when the participant began

287 wearing the exposed t-shirt, i.e. start of exposure.

288 Urine concentrations of, and mass excreted per urination for, BP-1 and BP-3 were highly

289 correlated (see Figures S4a and S4b of Supplementary Information). For all participants $\mathrm{R}^{2}$

290 values were 0.8 or greater. Although BP-1 has other possible sources and is also per se used as a

291 UV filter in consumer products, the correlation suggests that the measured BP-1 here is mainly

292 present as a metabolite of BP-3, similar to the metabolism of BP-3 in rats shown in

293 pharmacokinetic studies ${ }^{47,48}$. Both compounds exhibit peak concentrations within 4-8 hours of

294 the start of the exposure for subjects 1 and 2. A second peak is observed for subject 3 which is 295 due to a larger void volume of the previous sample (i.e. dilution) and accumulation overnight. It 
296 is also possible that there was some secondary exposure to BP-3 in the evening of the

297 intervention exposure. In all three subjects, the accumulated urinary excretion of BP-1 (Figure

298 2c) and BP-3 (Figure 2d) occurs faster during the 24h period after exposure.

299 Shown in Figure 3 are excretion rates for the sum of BP-1 and BP-3. This figure shows more 300 clearly than Figure 2 the effect of wearing dosed shirts. Excretion rates peak 4-8 hours after 301 donning the dosed shirts, then decay. Although Participant 3 has a much higher excretion rate 302 than Participants 1 or 2 , the dose pattern and the decay in the excretion rate is similar. While it is 303 possible that Participant 3 encountered a source of BP-3 prior to or after the experimental 304 exposure, the similarity in the pattern of the excretion rate suggests that this individual absorbed 305 most of the excreted BP-3 during the experiment. Excretion continues for 20+ hours after 306 exposure, suggesting that skin acts as a reservoir for BP-3 that accumulated during the $3 \mathrm{~h}$ that 307 BP-3 exposed shirts were worn. This is consistent with a recent study contrasting oral and 308 dermal uptake of bisphenol-A (BPA). After dermal exposure, Liu and Martin observed that 309 cumulative excretion increased linearly for 2 days, and half the participants still had detectable 310 urinary total BPA-d16 after 1 week. ${ }^{49}$ The rates shown in Figure 3 are based on the urination that 311 takes place at the end of an averaging period. Therefore, the first urination after exposure is 312 averaged over the entire period since the previous urination, which took place prior to exposure.

313 This makes it appear that elevated excretion occurs prior to wearing shirts; this is instead an 314 artifact of the method. 


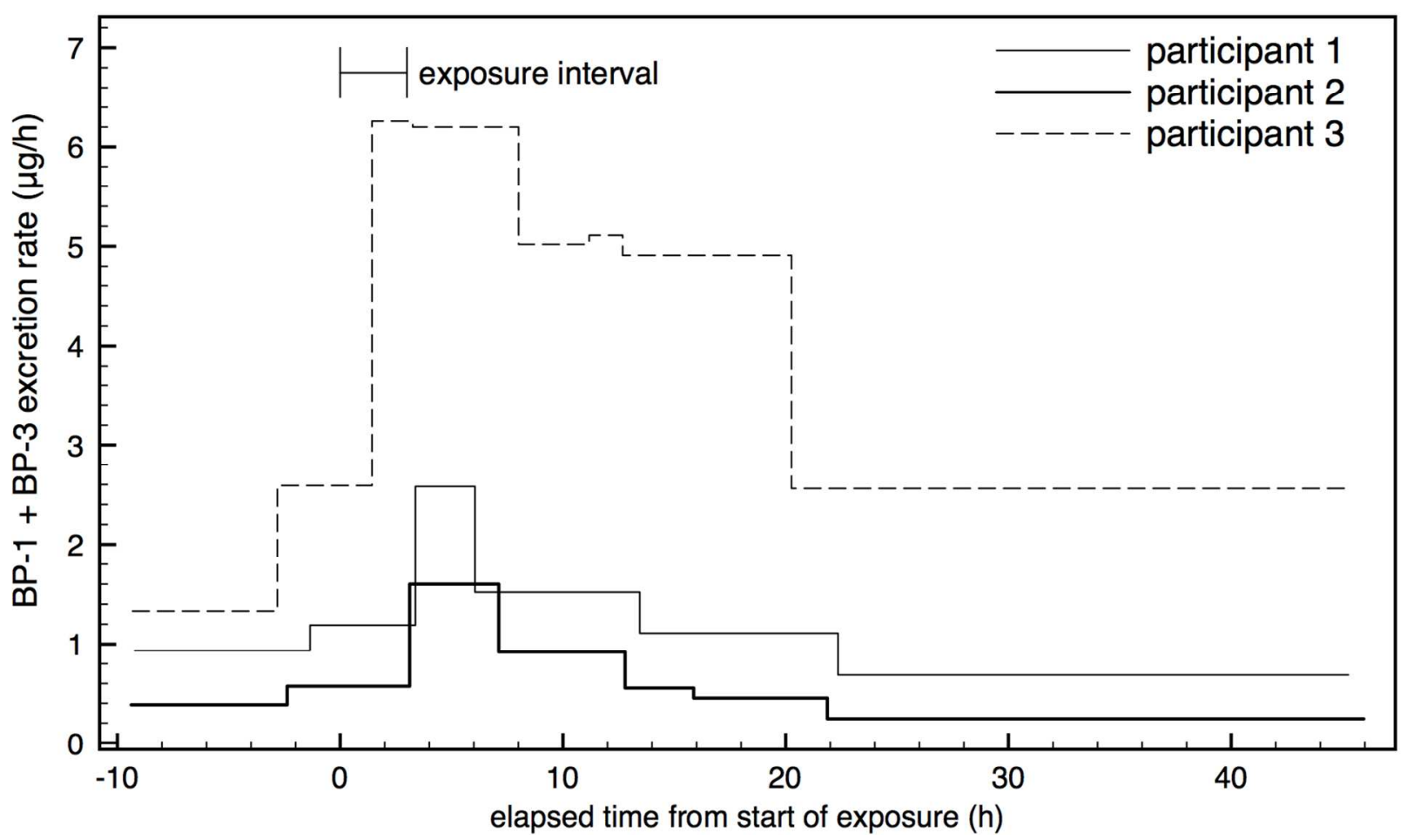

316 Figure 3. Urinary excretion rates $(\mu \mathrm{g} / \mathrm{h})$ of the sum of BP-1 and BP-3 for each participant. The

$317 \mathrm{x}$-axis shows the elapsed time, with " 0 " indicating when the participant dons the exposed t-shirt, 318 i.e. start of exposure.

319 The summed masses of BP-1 and BP-3 (BP-3 equivalent) excreted during the first 24 hours

320 attributable to wearing exposed t-shirts were 11, 9.9 and $82 \mu \mathrm{g}$ for participants 1,2 and 3

321 respectively. We believe these values represent a lower-bound on the amount absorbed during

322 the experiment. This value only accounts for the first $24 \mathrm{~h}$, whereas there is evidence that

323 excretion of BP-3 can occur for several days after exposure ${ }^{11,16}$. Additionally, other metabolites

324 of BP-3 may not be accounted for with this method. Uptake by inhalation during the exposure is

325 estimated to be negligible. The air concentrations in the breathing zone were below detection

326 limits. Using the detection limit as the upper limit on the air concentration in the exposure 
327 chamber, and an average inhalation rate of $0.7 \mathrm{~m}^{3} / \mathrm{h}$, uptake of BP-3 is less than $0.6 \mu \mathrm{g}$ by 328 inhalation.

329 It is apparent from the results shown in Table 3 and Figures 2-3 that participant 3 had

330 substantially larger dermal uptake of BP-3 than the other two participants. When corrected for 331 the pre-exposure excretion rates, participant 3's uptake is about 7-9 times greater than that of 332 participants 1 and 2 . Gonzalez et al. ${ }^{11}$ observed a wide range of excretion rates due to whole333 body application of sunscreen containing BP-3 for 25 subjects (male and female); the highest 334 percent excretion was 7.3 times greater than the lowest. In our study, this difference is not due to 335 differences in dosing of BP-3 to the shirts since the concentration in the shirt worn by participant 3363 was lower than that worn by participant 1 and similar to that worn by participant 2. Participant 3373 was 24 and 15 years older than participants 1 and 2, respectively. In a previous study 338 examining dermal uptake of diethylphthalate and di(n-butyl)phthalate directly from air ${ }^{23}$, older 339 subjects had substantially greater uptake than younger subjects. The authors speculated that this 340 may have been due to the thinner stratum corneum and reduced lipid content of older skin 341 compared to younger $\operatorname{skin}^{50}$. The reduced lipid content may be especially important for lipophilic

342 compounds such as phthalate esters and BP-3. In support of this, BP-3 has been shown to

343 accumulate in adipose (lipid) tissue ${ }^{51}$.Additionally, the shirt worn by participant 3 had noticeable 344 amounts of dry skin flakes, whereas the other shirts did not. Participant 3 may suffer from dry 345 skin, which is known to compromise the skin's barrier function ${ }^{52}$.

346 The higher transdermal uptake of subject 3 may also indicate that he had a different skin type 347 than the other two participants. Filaggrin is an epidermal protein that is crucial for skin barrier 348 function. We have recently shown that carriers of a filaggrin gene $(F L G)$ loss-of function 349 mutation have a significantly higher urinary excretion of several of the most common phthalate 
350 metabolites and parabens and a tendency to increased urinary excretion of both BP-3 and BP-1

351 compared to controls with no mutations ${ }^{5,53}$. Up to $10 \%$ of Europeans and Asians are

352 heterozygotes for FLG-loss-of function mutations, which causes dry skin, and are likely to

353 experience facilitated transfer of allergens such as nickel and chromium across the epidermis.

355 Table 3 also shows the average ratio of the urine concentrations of BP-1 and BP-3 for the 356 participants. Participant 3 had a lower value for BP-1/BP-3 (0.15) than participant $1(0.31)$ and

357 participant $2(0.35)$. This indicates less metabolism of the BP-3 absorbed through the skin of 358 participant 3 compared to the younger participants. As adults age, a decrease in the rate of 359 metabolism for chemicals such as BP-3 is not unusual and for BP-3 this is supported by higher 360 ratios reported in the urine of children: the value of BP-1/BP-3 was 0.75 and 0.55 for Danish

361 kindergarten children and adolescents respectively ${ }^{40,43}$. These results may also reflect differences 362 among the subjects in the amount of metabolism occurring in the skin compared to metabolism 363 that occurs after BP-3 enters the bloodstream ${ }^{54}$.

\section{Serum}

365 Serum concentrations of total BP-3 (sum of free and conjugated forms) are shown in Figure 4.

366 We found conjugated BP-3 in almost all samples and free BP-3 in about half of the samples

367 (Supplementary Table S3); the correlation between free and conjugated BP-3 was poor. BP-1

368 concentrations in the serum were below detection limits in all three participants. 4-HBP, a

369 possible metabolite of BP-3 $3^{55,56}$, was observed in all serum samples and a weak correlation

370 between the free and conjugated form was observed. There was no correlation between total BP-

3713 and 4-HBP in serum, suggesting that the source for 4-HBP exposure may be different from that

372 of BP-3. Free and total 4-MBP was measured in some of the serum samples, but again there was 
373 no correlation with BP-3, and it may derive from a different source. Total BP-3 was elevated

374 soon after initiating exposure, with concentrations peaking $2-5$ hours after putting on the shirts.

375 However, the impact of wearing BP-3 exposed shirts is not as obvious in blood samples as in the 376 urine samples. Considering all participants, the average concentration of the samples taken each 377 hour during and 2 hours after wearing the shirt was $0.26 \pm 0.13 \mathrm{ng} / \mathrm{ml}$, while the average over the 378 samples taken at 24 and 48 hours after exposure was $0.13 \pm 0.16 \mathrm{ng} / \mathrm{ml}$. As was the case in the 379 urine samples, participant 3 had higher total BP-3 serum concentrations than participants 1 and 2.

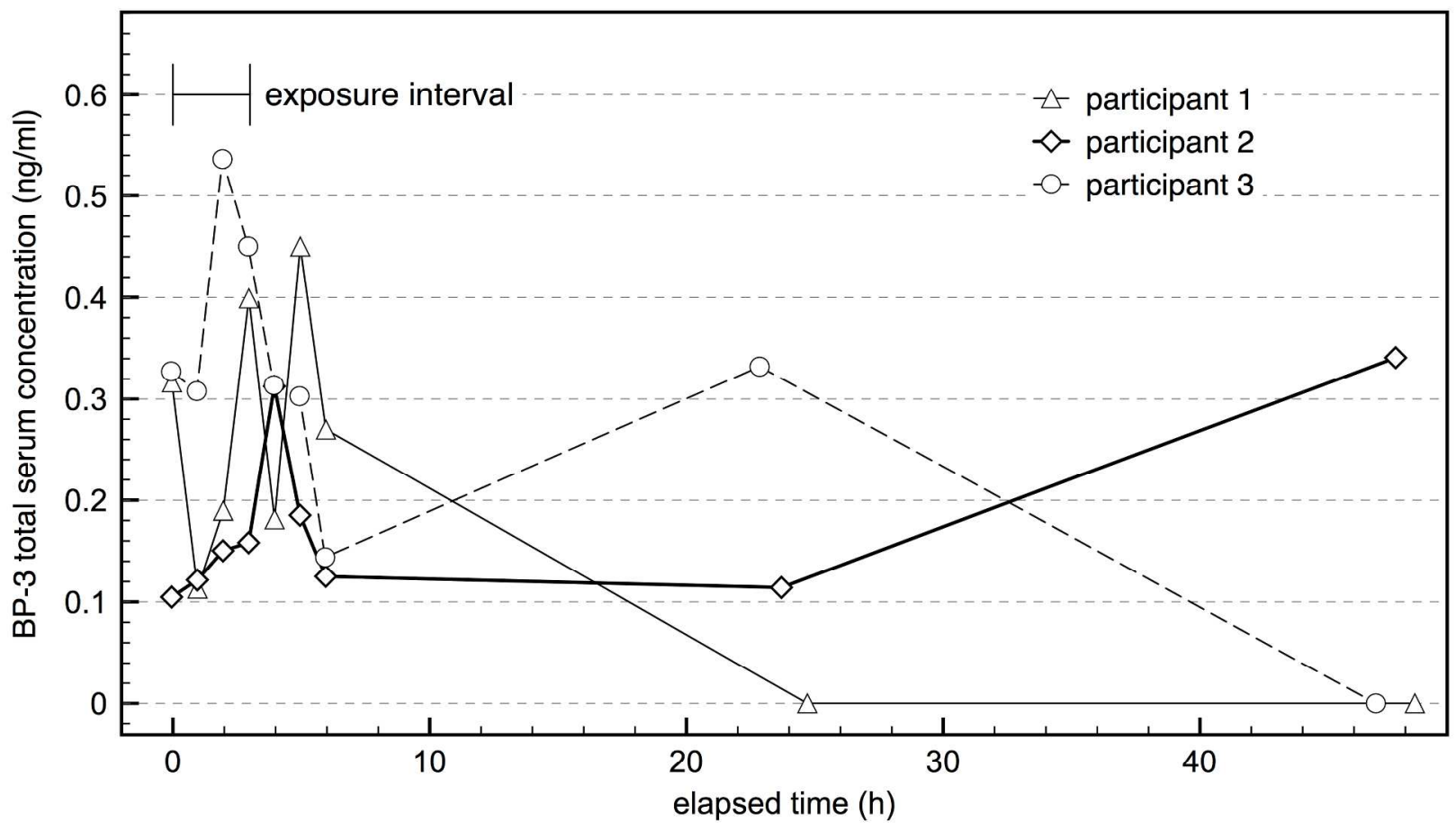

381 Figure 4. Serum concentrations of BP-3. The $\mathrm{x}$-axis shows the elapsed time from when the 382 participant dons the exposed t-shirt, i.e. start of exposure.

384 Dermal uptake is a dynamic and complex process. An airborne chemical first transfers to the skin 385 surface, then accumulates and transports through the skin layers to dermal capillaries. The 
compound or its metabolites are eventually excreted. Because of these dynamics, it is

challenging to extrapolate the results of this $3 \mathrm{~h}$ exposure to predict uptake associated with daily residential exposure to BP-3 that has sorbed to clothing from indoor air. Since uptake had not reached equilibrium, our observed excretion may be considered a lower-bound estimate of the steady-state uptake under these conditions. The background-corrected excreted mass of the sum of BP-3 and BP-1 during the first $24 \mathrm{~h}$, normalized by shirt-covered surface area $(0.5 * \mathrm{BSA})$ and dosing BP-3 air concentration $\left(4.4 \mu \mathrm{g} / \mathrm{m}^{3}\right)$ ranges from 2.7 to $18 \mu \mathrm{g} /\left(\mathrm{m}^{2}\right) /\left(\mu \mathrm{g} / \mathrm{m}^{3}\right)$ (Table 3$)$. This corresponds to a mass-normalized excretion rate of 52 to $330 \mathrm{ng} / \mathrm{kg} / \mathrm{hr}$. The steady-state uptake from a shirt equilibrated with air in the dosing chamber, at a BP-3 concentration of $4.4 \mu \mathrm{g} / \mathrm{m}^{3}$, can be estimated using the model described in Morrison et al. ${ }^{57}$. If the gap between skin and shirt is $1 \mathrm{~mm}$, the model predicts a steady-state BP-3 uptake of about $1000 \mathrm{ng} / \mathrm{kg} / \mathrm{h}$. Therefore, in only a $3 \mathrm{~h}$ exposure, the mass (summed BP-1 and BP-3) excreted is 5-30\% of the steady-state estimate of BP-3 uptake; as noted earlier, the excreted mass is an underestimate of the mass absorbed.

The steady-state uptake model can be used to predict uptake of BP-3 from clothing that has

400 equilibrated with air in residences. Wan et al. ${ }^{25}$ reported residential airborne concentrations that

401 ranged between 0.07 and $18 \mathrm{ng} / \mathrm{m}^{3}$. Here, we assume that a reasonable airborne concentration 402 range is $1 / 2$ to twice the median reported concentration of $1.64 \mathrm{ng} / \mathrm{m}^{3}\left(0.82\right.$ to $\left.3.28 \mathrm{ng} / \mathrm{m}^{3}\right)$, which

403 is consistent with the range of exposure estimates provided in Wan et al. ${ }^{25}$ Using the same

404 method as above ${ }^{57}$ and an adult surface area to mass ratio of $0.025 \mathrm{~m}^{2} / \mathrm{kg}^{58}$, steady-state uptake 405 from equilibrated clothing is estimated to range between 8.8 to $35 \mathrm{ng} / \mathrm{kg} /$ day. This is similar to 406 the $6-7 \mathrm{ng} / \mathrm{kg} /$ day estimated by Xue et al. ${ }^{33}$, using a US EPA exposure estimation method ${ }^{58}$, for 407 dermal uptake of BP-3 for infants wearing newly purchased clothing. (Although BP-1 has been 
408 measured in house dust ${ }^{59}$, we were unable to find measured indoor airborne concentrations of 409 BP-1. Therefore, we did not estimate dermal uptake of BP-1 by the airborne route.)

410 The range of 8.8 to $35 \mathrm{ng} / \mathrm{kg} /$ day is consistent with the lower daily dose estimates in various 411 populations. Based on concentrations in urine, Gao et al. ${ }^{45}$ estimated the mean daily excretion 412 rate in a Chinese population to be $27 \mathrm{ng} / \mathrm{kg} /$ day of BP-3. In Denmark, the median daily excretion 413 rate in kindergarten children was estimated to be $136 \mathrm{ng} / \mathrm{kg} / \mathrm{day}$ at summer time and 32 $414 \mathrm{ng} / \mathrm{kg} /$ day at winter $^{40}$, while the median daily excretion rate in Danish adolescents (17-21 year 415 old, boys and girls) was estimated to be $33 \mathrm{ng} / \mathrm{kg} /$ day in samples collected in winter time $\mathrm{e}^{43}$. 416 Based on a survey of U.S. residents, Calafat et al. ${ }^{17}$ reported geometric mean urine 417 concentrations for BP-3 of $30.7 \mathrm{ng} / \mathrm{ml}$ for females $(\mathrm{n}=1288)$ and $16.8 \mathrm{ng} / \mathrm{ml}$ for males $(\mathrm{n}=$ 418 1229). Daily excretion rates can be estimated assuming an average urine volume of $1.3 \mathrm{~L} / \mathrm{day}^{60}$ 419 and an average body weight of $75 \mathrm{~kg}$ for females and $89 \mathrm{~kg}$ for males ${ }^{61}$. The resulting estimated 420 excretion rates are $532 \mathrm{ng} / \mathrm{kg} /$ day for females and $245 \mathrm{ng} / \mathrm{kg} /$ day for males. Dewalque et al. ${ }^{46}$ 421 reported a mean urine concentration of $1.3 \mathrm{ng} / \mathrm{ml}$ in a Belgian population, which corresponds to $42222 \mathrm{ng} / \mathrm{kg} /$ day using the same method. Overall, the observed uptake rates and model predictions 423 suggest that the clothing-enhanced dermal uptake route is competitive with other exposure 424 routes, especially for individuals that have intentionally avoided personal care products 425 containing UV filters.

426 For three male volunteers, wearing cotton shirts that had been exposed to airborne BP-3 resulted 427 in dermal uptake of this chemical as evidenced by BP-3 in their blood as well as both BP-3 and 428 BP-1 (a metabolite) in their urine. In an average adult population, direct applications of 429 sunscreen, cosmetics and other personal care products are anticipated to be the dominant 430 contributors to BP-3 exposure. However, given that BP-3 is commonly present in indoor air ${ }^{25}$, 
431 this unintentional exposure pathway (i.e., dermal uptake from air and clothing) is likely to

432 contribute meaningfully to the overall body-burden of BP-3. For infants and children not using

433 BP-3 containing lotions, inadvertent exposure from air and clothing may be the major source of

434 BP-3 in their bodies.

\section{Acknowledgements}

436 We are grateful for the assistance of volunteers and skilled technical assistance by Stine E.

437 Andersen, Department of Growth and Reproduction, Rigshospitalet. This research was

438 supported, in part, by the Otto Mønsted Guest Professorship of the Technical University of

439 Denmark, and International Center for Research and Research Training in Endocrine Disruption

440 of Male Reproduction and Child Health (EDMaRC), Rigshospitalet, University of Copenhagen,

441 Denmark. This material is also based upon work supported by the National Science Foundation

442 under grant number 1336807.

443 References

(1) MST. Survey of chemical substances in consumer products; 142; Ministry of Environment and Food of Denmark. Environmental Protection Agency., 2015.

(2) Louis, G. M. B.; Kannan, K.; Sapra, K. J.; Maisog, J.; Sundaram, R. Urinary concentrations of benzophenone-type ultraviolet radiation filters and couples' fecundity. Am. J. Epidemiol. 2014, 180 (12), 1168-1175.

(3) CDC. Fourth National report on Human Exposure to Environmental Chemicals (2009) with updated tables, January 2017; Centers for Disease Control and Prevention, 2017.

(4) Zhang, T.; Sun, H.; Qin, X.; Wu, Q.; Zhang, Y.; Ma, J.; Kannan, K. Benzophenone-type UV filters in urine and blood from children, adults, and pregnant women in China: partitioning between blood and urine as well as maternal and fetal cord blood. Sci. Total Environ. 2013, $461,49-55$.

(5) Joensen, U. N.; Jørgensen, N.; Thyssen, J.; Petersen, J. H.; Szecsi, P. B.; Stender, S.; Andersson, A.-M.; Skakkebaek, N. E.; Frederiksen, H. Exposure to phenols, parabens and UV filters: Associations with loss-of-function mutations in the filaggrin gene in men from the general population. Environ. Int. 2017, In Press. 
$460 \quad$ (6) Hass, U.; Christiansen, S.; Axelstad, A.; Boberg, J.; Andersson, A. M.; Skakkebaek, N. E.; Bay, K.;

461

462

463

464

465

466

467

468

469

470

471

472

473

474

475

476

477

478

479

480

481

482

483

484

485

486

487

488

489

490

491

492

493

494

495

496

497

498

499

500

501

502

503

504

505

506

507

508

509

Holbech, H.; Kinnberg, K. L.; Bjerregaard, P. Evaluation of 22 SIN List 2.0 substances according to the Danish proposal on criteria for endocrine disruptors, Danish Centre on Endocrine Disrupters; SIN67169 and Annex; Danish Centre on Endocrine Disrupters, 2012.

(7) Kinnberg, K. L.; Petersen, G. I.; Albrektsen, M.; Minghlani, M.; Awad, S. M.; Holbech, B. F.; Green, J. W.; Bjerregaard, P.; Holbech, H. Endocrine-disrupting effect of the ultraviolet filter benzophenone-3 in zebrafish, Danio rerio. Environ. Toxicol. Chem. 2015, 34 (12), 2833-2840.

(8) Rehfeld, A.; Dissing, S.; Skakkebaek, N. E. Chemical UV filters mimic the effect of progesterone on $\mathrm{Ca}(2+)$ signaling in human sperm cells. Endocrinology 2016, 157 (11), 4297-4308.

(9) Suzuki, T.; Kitamura, S.; Khota, R.; Sugihara, K.; Fujimoto, N.; Ohta, S. Estrogenic and antiandrogenic activities of 17 benzophenone derivatives used as UV stabilizers and sunscreens. Toxicol. Appl. Pharmacol. 2005, 203 (1), 9-17.

(10) Kunisue, T.; Chen, Z.; Louis, G. M. B.; Sundaram, R.; Hediger, M. L.; Sun, L.; Kannan, K. Urinary concentrations of benzophenone-type UV filters in US women and their association with endometriosis. Environ. Sci. Technol. 2012, 46 (8), 4624.

(11) Gonzalez, H.; Farbrot, A.; Larkö, O.; Wennberg, A. Percutaneous absorption of the sunscreen benzophenone-3 after repeated whole-body applications, with and without ultraviolet irradiation. Br. J. Dermatol. 2006, 154 (2), 337-340.

(12) Gonzalez, H.; Farbrot, A.; Larkö, O. Percutaneous absorption of benzophenone-3, a common component of topical sunscreens. Clin. Exp. Dermatol. 2002, 27 (8), 691-694.

(13) Schauer, U. M.; Völkel, W.; Heusener, A.; Colnot, T.; Broschard, T. H.; von Landenberg, F.; Dekant, W. Kinetics of 3-(4-methylbenzylidene) camphor in rats and humans after dermal application. Toxicol. Appl. Pharmacol. 2006, 216 (2), 339-346.

(14) Sarveiya, V.; Risk, S.; Benson, H. A. Liquid chromatographic assay for common sunscreen agents: application to in vivo assessment of skin penetration and systemic absorption in human volunteers. J. Chromatogr. B 2004, 803 (2), 225-231.

(15) Janjua, N. R.; Mogensen, B.; Andersson, A.-M.; Petersen, J. H.; Henriksen, M.; Skakkebæk, N. E.; Wulf, H. C. Systemic absorption of the sunscreens benzophenone-3, octyl-methoxycinnamate, and 3-(4-methyl-benzylidene) camphor after whole-body topical application and reproductive hormone levels in humans. J. Invest. Dermatol. 2004, 123 (1), 57-61.

(16) Janjua, N.; Kongshoj, B.; Andersson, A.; Wulf, H. C. Sunscreens in human plasma and urine after repeated whole-body topical application. J. Eur. Acad. Dermatol. Venereol. 2008, 22 (4), 456-461.

(17) Calafat, A. M.; Wong, L.-Y.; Ye, X.; Reidy, J. A.; Needham, L. L. Concentrations of the sunscreen agent benzophenone-3 in residents of the United States: National Health and Nutrition Examination Survey 2003-2004. Environ. Health Perspect. 2008, 116 (7), 893.

(18) Frederiksen, H.; Jensen, T. K.; Jørgensen, N.; Kyhl, H. B.; Husby, S.; Skakkebæk, N. E.; Main, K. M.; Juul, A.; Andersson, A.-M. Human urinary excretion of non-persistent environmental chemicals: an overview of Danish data collected between 2006 and 2012. Reproduction 2014, 147 (4), 555-565.

(19) Zamoiski, R. D.; Cahoon, E. K.; Freedman, D. M.; Linet, M. S. Self-reported sunscreen use and urinary benzophenone-3 concentrations in the United States: NHANES 2003-2006 and 2009-2012. Environ. Res. 2015, 142, 563-567.

(20) Harley, K. G.; Kogut, K.; Madrigal, D. S.; Cardenas, M.; Vera, I. A.; Meza-Alfaro, G.; She, J.; Qi, G.; Zahedi, R.; Bradman, A. Reducing phthalate, paraben, and phenol exposure from personal care products in adolescent girls: findings from the HERMOSA Intervention Study. Environ. Health Perspect. Online 2016, 124 (10), 1600.

(21) Liao, C.; Kannan, K. Widespread occurrence of benzophenone-type UV light filters in personal care products from China and the United States: an assessment of human exposure. Environ. Sci. Technol. 2014, 48 (7), 4103-4109. 
510 (22) Weschler, C. J.; Nazaroff, W. W. SVOC exposure indoors: Fresh look at dermal pathways. Indoor Air 2012, 22 (5), 356-377.

(23) Weschler, C. J.; Beko, G.; Koch, H. M.; Salthammer, T.; Schripp, T.; Toftum, J.; Clausen, G. Transdermal uptake of diethyl- and di(n-butyl) phthalate directly from air: experimental verification. Environ. Health Perspect. 2015, 123 (10), 928-934.

(24) Morrison, G. C.; Weschler, C. J.; Bekö, G. Dermal uptake directly from air under transient conditions: advances in modeling and comparisons with experimental results for human subjects. Indoor Air 2016, 26 (6), 913-924.

(25) Wan, Y.; Xue, J.; Kannan, K. Occurrence of benzophenone-3 in indoor air from Albany, New York, USA, and its implications for inhalation exposure. Sci. Total Environ. 2015, 537, 304308.

(26) Piotrowski, J. Further investigations on the evaluation of exposure to nitrobenzene. Br. J. Ind. Med. 1967, 24, 60-65.

(27) Morrison, G. C.; Weschler, C. J.; Bekö, G.; Koch, H. M.; Salthammer, T.; Schripp, T.; Toftum, J.; Clausen, G. Role of clothing in both accelerating and impeding dermal absorption of airborne SVOCs. J. Expo. Sci. Environ. Epidemiol. 2016, 26 (1), 113-118.

(28) Bekö, G.; Morrison, G.; Weschler, C. J.; Koch, H. M.; Pälmke, C.; Salthammer, T.; Schripp, T.; Toftum, J.; Clausen, G. Measurements of dermal uptake of nicotine directly from air and clothing. Indoor Air 2017, 27 (2), 427-433.

(29) Blum, A.; Gold, M. D.; Ames, B. N.; Jones, F. R.; Hett, E. A.; Dougherty, R. C.; Horning, E. C.; Dzidic, I.; Carroll, D. I.; Stillwell, R. N.; et al. Children absorb tris-BP flame retardant from sleepwear: urine contains the mutagenic metabolite, 2,3-dibromopropanol. Science 1978, 201 (4360), 1020-1023.

(30) Appel, K. E.; Gundert-Remy, U.; Fischer, H.; Faulde, M.; Mross, K. G.; Letzel, S.; Rossbach, B. Risk assessment of Bundeswehr (German Federal Armed Forces) permethrin-impregnated battle dress uniforms (BDU). Int. J. Hyg. Environ. Health 2008, 211 (1-2), 88-104.

(31) Kegel, P.; Letzel, S.; Rossbach, B. Biomonitoring in wearers of permethrin impregnated battle dress uniforms in Afghanistan and Germany. Occup. Environ. Med. 2014, 71 (2), 112-117.

(32) Rossbach, B.; Appel, K. E.; Mross, K. G.; Letzel, S. Uptake of permethrin from impregnated clothing. Toxicol. Lett. 2010, 192 (1), 50-55.

(33) Xue, J.; Liu, W.; Kannan, K. Bisphenols, benzophenones, and bisphenol A diglycidyl ethers in textiles and infant clothing. Environ. Sci. Technol. 2017.

(34) Saini, A.; Rauert, C.; Simpson, M. J.; Harrad, S.; Diamond, M. L. Characterizing the sorption of polybrominated diphenyl ethers (PBDEs) to cotton and polyester fabrics under controlled conditions. Sci. Total Environ. 2016, 563-564, 99-107.

(35) Saini, A.; Okeme, J.; Mark Parnis, J.; McQueen, R.; Diamond, M. From air to clothing: characterizing the accumulation of semi-volatile organic compounds to fabrics in indoor environments. Indoor Air 2016, 27 (3), 631-641.

(36) Piadé, J. J.; D’Andrés, S.; Sanders, E. B. Sorption phenomena of nicotine and ethenylpyridine vapors on different materials in a test chamber. Environ. Sci. Technol. 1999, 33 (12), 20462052.

(37) Morrison, G.; Li, H.; Mishra, S.; Buechlein, M. Airborne phthalate partitioning to cotton clothing. Atmos. Environ. 2015, 115, 149-152.

(38) Morrison, G.; Shakila, N. V.; Parker, K. Accumulation of gas-phase methamphetamine on clothing, toy fabrics, and skin oil. Indoor Air 2015, 25 (4), 405-414.

(39) Cao, J.; Weschler, C. J.; Luo, J.; Zhang, Y. Cm-History Method, a Novel Approach to Simultaneously Measure Source and Sink Parameters Important for Estimating Indoor Exposures to Phthalates. Env. Sci Technol 2016, 50, 825-834.

(40) Krause, M.; Andersson, A.-M.; Skakkebaek, N. E.; Frederiksen, H. Exposure to UV filters during summer and winter in Danish kindergarten children. Environ. Int. 2017, 99, 177-184. 
560 (41) European Union. Commission Regulation (EU) 2017/238 of 10 February 2017 amending Annex

561

562

563

564

565

566

567

568

569

570

571

572

573

574

575

576

577

578

579

580

581

582

583

584

585

586

587

588

589

590

591

592

593

594

595

596

597

598

599

600

601

602

603

604

605

606

607

608
VI to Regulation (EC) No 1223/2009 of the European Parliament and of the Council on cosmetic products; 2017; Vol. (EU) 2017/238.

(42) DuBois, D.; DuBois, D. A formula to estimate the approximate surface area if height and weight be known. Arch. Intern. Med. 1916, 17, 863-871.

(43) Frederiksen, H.; Nielsen, O.; Skakkebaek, N. E.; Juul, A.; Andersson, A.-M. UV filters analyzed by isotope diluted TurboFlow-LC-MS/MS in urine from Danish children and adolescents. Int. J. Hyg. Environ. Health 2016.

(44) Heffernan, A.; Baduel, C.; Toms, L.; Calafat, A.; Ye, X.; Hobson, P.; Broomhall, S.; Mueller, J. Use of pooled samples to assess human exposure to parabens, benzophenone-3 and triclosan in Queensland, Australia. Environ. Int. 2015, 85, 77-83.

(45) Gao, C.; Liu, L.; Ma, W.; Zhu, N.; Jiang, L.; Li, Y.-F.; Kannan, K. Benzonphenone-type UV filters in urine of Chinese young adults: concentration, source and exposure. Environ. Pollut. 2015, 203, 1-6.

(46) Dewalque, L.; Pirard, C.; Charlier, C. Measurement of urinary biomarkers of parabens, benzophenone-3, and phthalates in a Belgian population. BioMed Res. Int. 2014, 2014.

(47) Jeon, H.-K.; Sarma, S. N.; Kim, Y.-J.; Ryu, J.-C. Toxicokinetics and metabolisms of benzophenone-type UV filters in rats. Toxicology 2008, 248 (2), 89-95.

(48) Okereke, C. S.; Abdel-Rhaman, M. S.; Friedman, M. A. Disposition of benzophenone-3 after dermal administration in male rats. Toxicol. Lett. 1994, 73 (2), 113-122.

(49) Liu, J.; Martin, J. W. Prolonged exposure to bisphenol A from single dermal contact events. Environ. Sci. Technol. 2017, In press.

(50) Harvell, J.; Maibach, H. I. Percutaneous-absorption and inflammation in aged skin - a review. J. Am. Acad. Dermatol. 1994, 31 (6), 1015-1021.

(51) Wang, L.; Asimakopoulos, A. G.; Kannan, K. Accumulation of 19 environmental phenolic and xenobiotic heterocyclic aromatic compounds in human adipose tissue. Environ. Int. 2015, 78, 45-50.

(52) Halling-Overgaard, A.; Kezic, S.; Jakasa, I.; Engebretsen, K.; Maibach, H.; Thyssen, J. Skin absorption through atopic dermatitis skin: a systematic review. Br. J. Dermatol. 2016.

(53) Joensen, U. N.; Jørgensen, N.; Meldgaard, M.; Frederiksen, H.; Andersson, A.-M.; Menné, T.; Johansen, J. D.; Carlsen, B. C.; Stender, S.; Szecsi, P. B. Associations of filaggrin gene loss-offunction variants with urinary phthalate metabolites and testicular function in young Danish men. Environ. Health Perspect. Online 2014, 122 (4), 345.

(54) Hopf, N.; Berthet, A.; Vernez, D.; Langard, E.; Spring, P.; Gaudin, R. Skin permeation and metabolism of di (2-ethylhexyl) phthalate (DEHP). Toxicol. Lett. 2014, 224 (1), 47-53.

(55) Bae, J.; Kim, S.; Kannan, K.; Louis, G. M. B. Couples' urinary concentrations of benzophenonetype ultraviolet filters and the secondary sex ratio. Sci. Total Environ. 2016, 543, 28-36.

(56) Kang, H.-S.; Ko, A.; Kwon, J.-E.; Kyung, M.-S.; Im Moon, G.; Park, J.-H.; Lee, H.-S.; Suh, J.-H.; Lee, J.-M.; Hwang, M.-S. Urinary benzophenone concentrations and their association with demographic factors in a South Korean population. Environ. Res. 2016, 149, 1-7.

(57) Morrison, G. C.; Weschler, C. J.; Bekö, G. Dermal uptake of phthalates from clothing: Comparison of model to human participant results. Indoor Air 2017, 27 (3), 642-649.

(58) USEPA. Exposure Factors Handbook: 2011 Edition; EPA/600/R-090/052F; US Environmental Protection Agency: Washington D.C, 2011.

(59) Wang, L.; Asimakopoulos, A. G.; Moon, H.-B.; Nakata, H.; Kannan, K. Benzotriazole, benzothiazole, and benzophenone compounds in indoor dust from the United States and East Asian countries. Environ. Sci. Technol. 2013, 47 (9), 4752-4759.

(60) Hays, S. M.; Aylward, L. L.; Blount, B. C. Variation in Urinary Flow Rates According to Demographic Characteristics and Body Mass Index in NHANES: Potential Confounding of 
609

610

611

612

613

614

615

616

Associations between Health Outcomes and Urinary Biomarker Concentrations. Environ. Health Perspect. 2015, 123 (4), 293-400.

(61) CDC. Anthropometric Reference Data for Children and Adults: United States, 2007-2010; Vital and health statistics. Series 11, Data from the National Health Examination Survey, the National Health and Nutrition Examination Surveys, and the Hispanic Health and Nutrition Examination Survey ; no. 252; HHS publication ; no. (PHS) 2012-1602; Centers for Disease Control and Prevention. National Health and Nutrition Examination Survey (NHANES), 2012. 

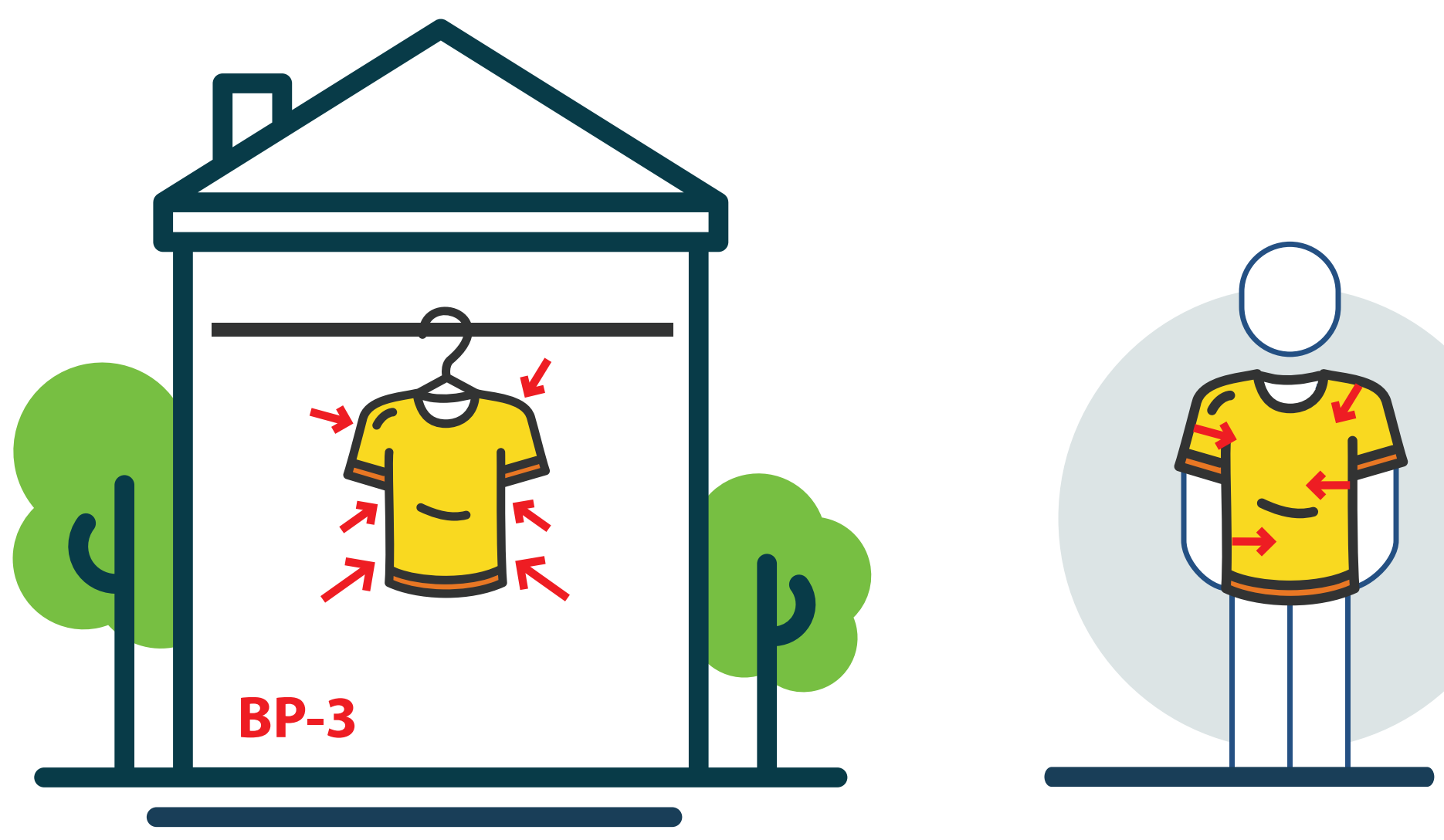
24 hour urine pool day 1 (all individual spot urine and the $1^{\text {st }}$ morning sample from morning 2 pooled)

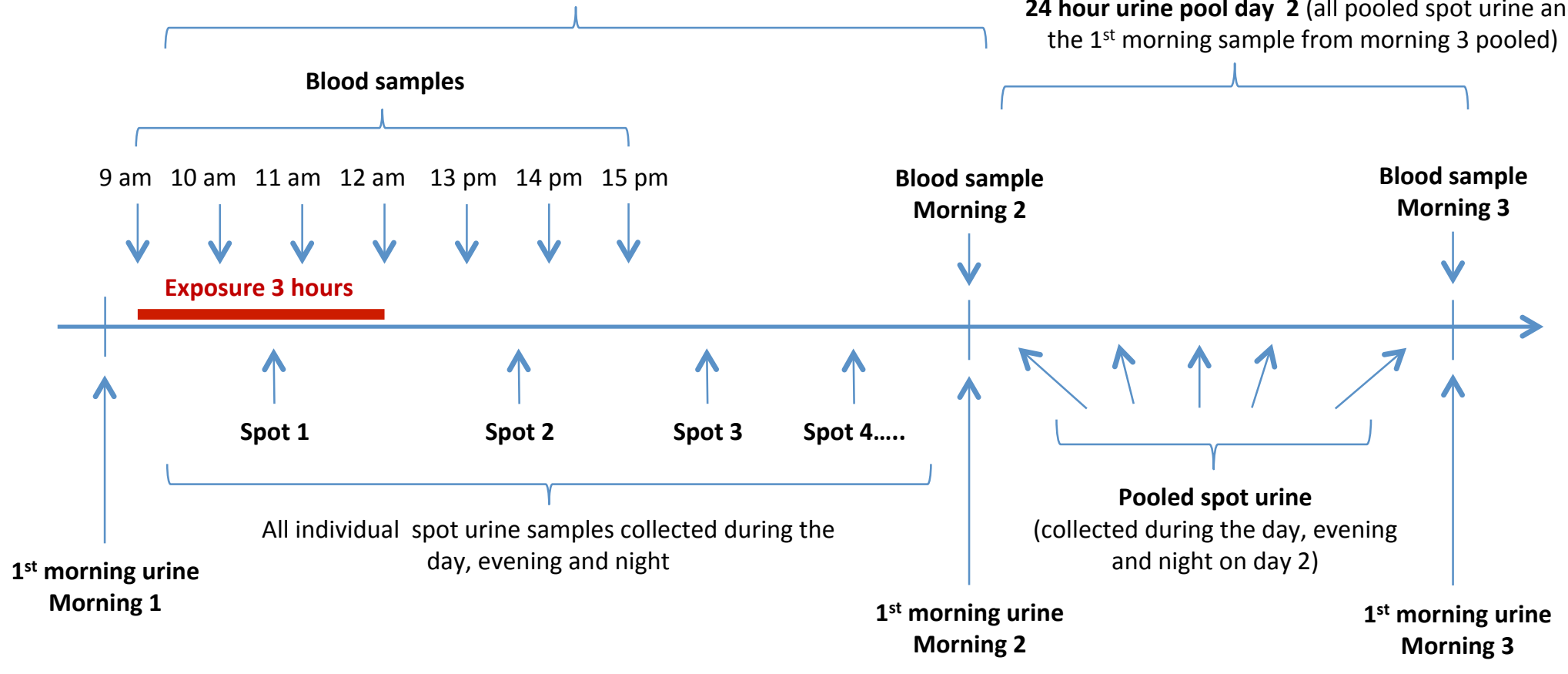



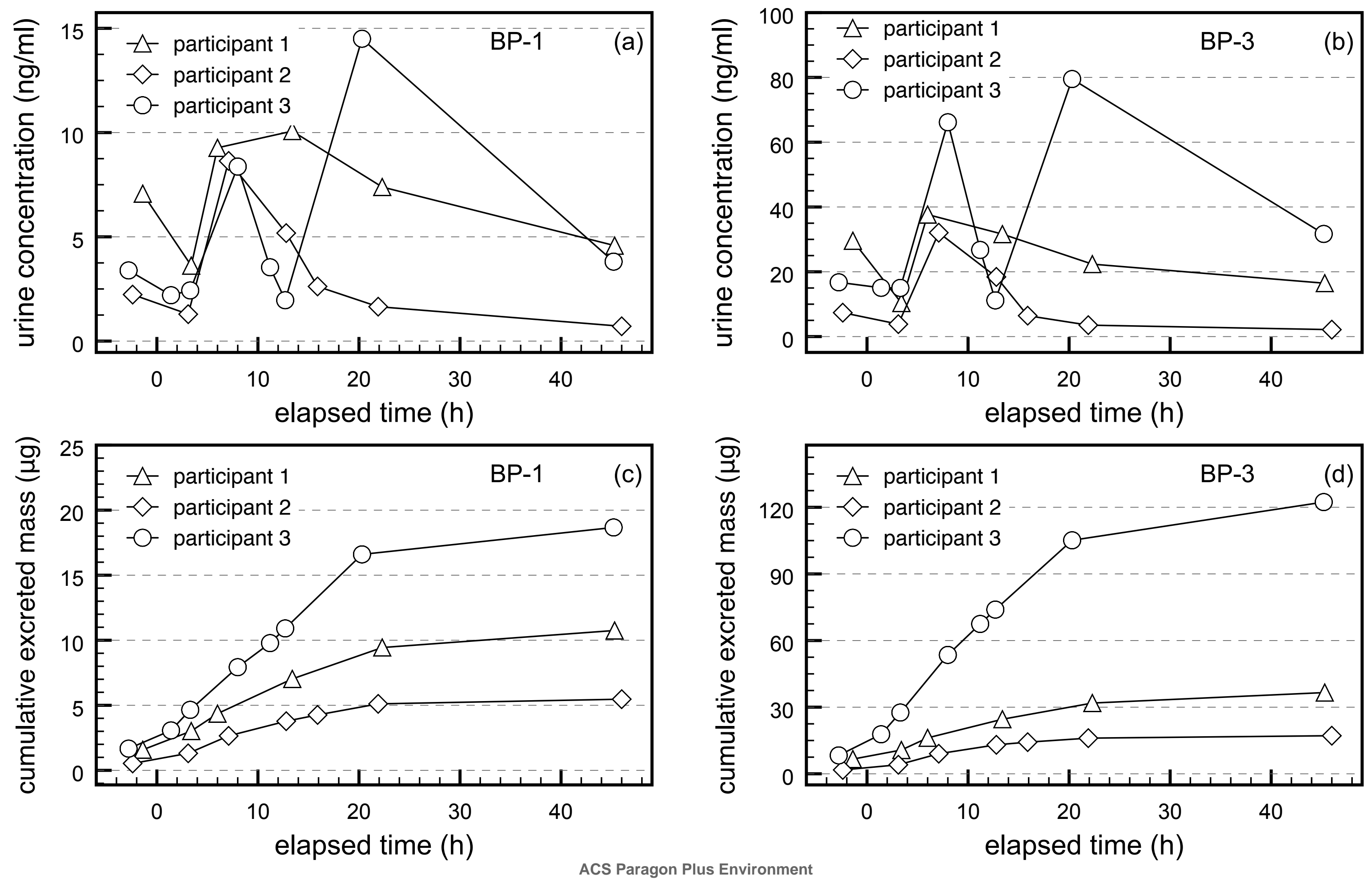


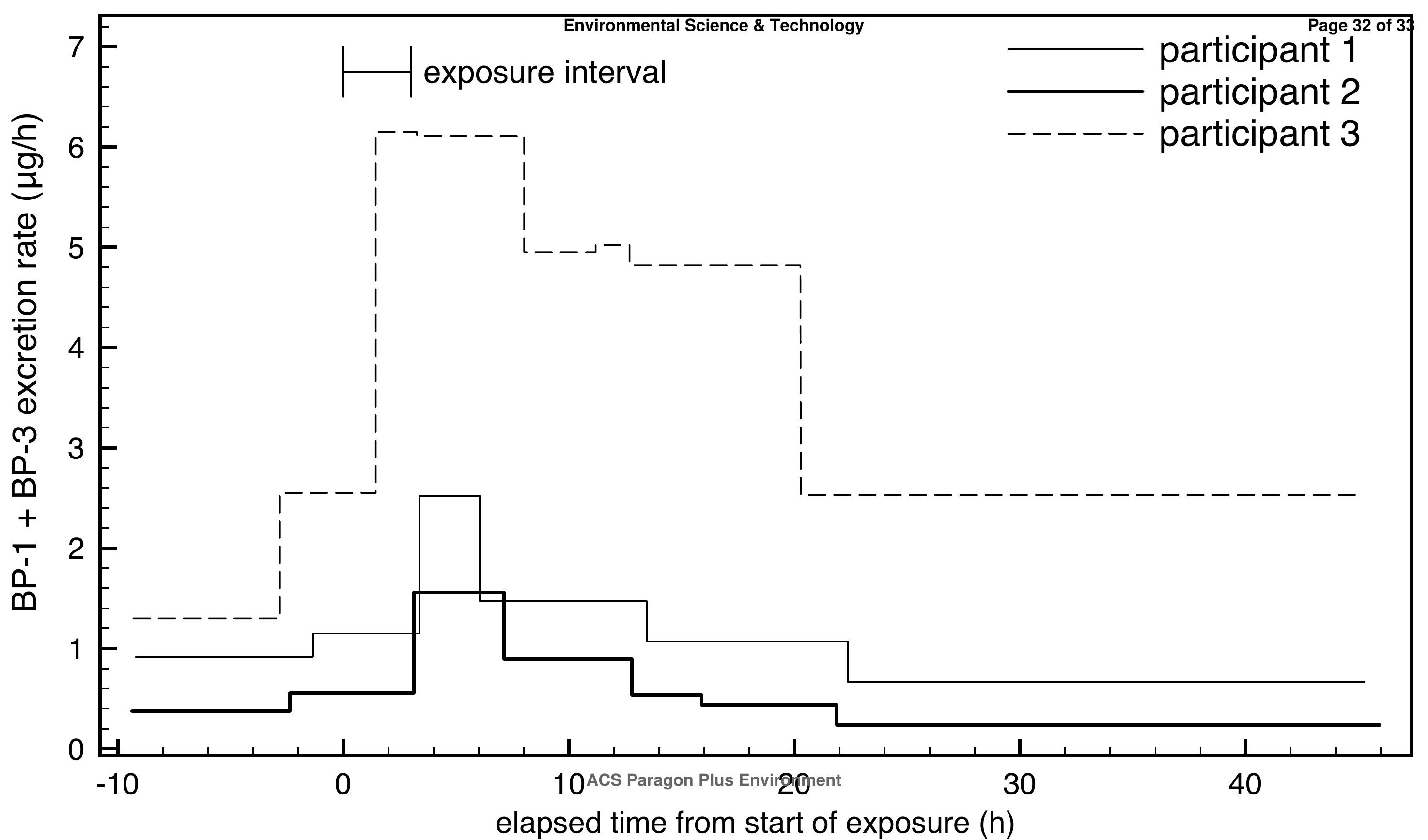


